\title{
Wound Closure Techniques in Ayurveda: A Short Review
}

Authors

\section{Dr. Kumar A.K ${ }^{1}$, Dr. P. Hemantha Kumar ${ }^{2}$, Dr. Narinder Singh ${ }^{3}$}

${ }^{1}$ Ph.D. Scholar in P.G. Department of Shalya Tantra, N.I.A. Jaipur Rajasthan, India

${ }^{2}$ Professor and Head P.G. Department of Shalya Tantra, N.I.A., Jaipur Rajasthan, India

${ }^{3}$ Lecture P.G. Department of Shalya Tantra, N.I.A., Jaipur Rajasthan, India

Corresponding Author

\section{Dr. Kumar A.K}

Plot no.17 Brahm Puri, Jaipur, Rajasthan,India

Emaildr.alokv@gmail.com mob.7597499939

\begin{abstract}
In surgical practice suturing is very important procedure. It is equally important procedure in both traumatic wound as well as in the elective surgery. Ayurveda is the most ancient medical science in our civilization. Ayurvedic acharyas has describes the Asthvidh Shalya Karma for various surgical disorders. Suturing i.e. Sevana Karma in one of them. Suturing is utilized for closing the wounds or/and ligating the bleeding vessels during surgery. Ayurvedic acharyas very well know the methods of suturing and its importance in practice and described well in various classical literature of Ayurveda. In modern day surgical practice we all follow the same principle without change. In present review study a humble effort is made to elaborate the ancient principle of wound closer.
\end{abstract}

Key words: Sevana karma, Shalya Karma

\section{Introduction}

Ayurveda is the most ancient medical science. It has antiquity goes back to the 'Vedas.' Ayurveda is aupang of "Atharva Veda", Ancient Indian Surgery was a highly skilled branch of Ayurvedic medicine and known as Shalya Tantra. Eight types of surgical procedures described as "Ashtavidha Shastrakarma" are means and methods to treat the surgical diseases at that time. Ashtavidha Shastrakarma included Chedana (Excision), Bhedana (Incision), Lekhana (Scraping), Vedhana (Puncture), Eshana (Probing), Aaharana (Extraction), Vishravana
(Drainage) and Sevana (Suturing). Commonly suturing is the last surgical procedure which makes that particular surgery successful if done perfectly otherwise complete procedure will ruined. Acharya Sushruta describes suturing in very detail in his samhita on sutra sthan ${ }^{3}$. Suturing is not a new technique but is a known procedure since ancient era. This is the branch basically evolved for the purpose of wound healing and its management. Sevana Karma i.e. suturing is one of the prime surgical procedures and has got great importance as the success of 
surgery depends on careful apposition of tissues and wound healing.

Sushruta the great Indian Surgeon who had given a complete account on wound healing and various techniques of wound healing used for various types of wounds. Sushruta defined the suturing procedure as a process of tying two ends of thread for union of wound edges and is done with the help of needle and appropriate suturing material.

The purpose of Sevana Karma is to approximate the wound edges for proper and faster healing i.e. Vrana Sandhan ${ }^{4}$. Sandhan means to unite, to heal. Aim is to unite, repair and support the injured tissue until healing is completed. This will achieve complete haemostasis and normal restoration of tissue function.

With advancement of time, science is expanding its wings in every field. But basic principles remain always unchanged. That's why modern surgery also follows all those ancient surgical principles. Acharya Sushruta had described in details about how to perform suturing in a proper way avoiding complications. This review article is based on suturing principle laid by Acharya Sushruta in concern to Vrana Sandhan Karma i.e. wound healing.

\section{Aims and objective}

1. To appraise, elaborate and discuss the various concepts of wound closure described in Sushruta samhita.

2. To described the various methods of wound closure in Sushruta samhita and correlate them with the modern day surgical techniques.

\section{Material and methods}

The all reference of Sandhan Karma are collected and compiled from Sushruta samhita and other Ayurvedic classics and various modern textbooks of surgery. The various methods are discussed with their importance of there in enhancing wound healing.

\section{Observations}

Sevana Karma described in detail in various classical literature of Ayurveda especially in Brihatrye. Acharya charaka included Sevana Karma in Shatvidha Shalya Karma in chikitsa sthanam of Dividhvraniya chikitsa chapter ${ }^{5}$. Acharya Sushruta advocated Sevana Karma in the Asthvidha Shalya Karma for the management of surgical disease and described in detail in Asthvidhshashtrakarmiyam adhyayay of sutra sthan. In this chapter he described all the aspects of suturing regarding managements of wound. As we all know Sushruta the father of surgery in India ${ }^{6}$ so we accept the principles laid by sushruta for wound management.

$\mathrm{He}$ describes all the aspects regarding Sevana Karma as preparation of wound for suturing, methods of suturing, required material used in wound closure, indications, contraindication, benefits of suturing and complication of incorrect suturing etc.

\section{Preparation of wound for closure}

Before suturing the wound, it should be cleaned thoroughly. The devitalized tissue or any foreign material like dirt, dust, hair, sequestrations of bones, clotted blood all need to be removed from the wound $d^{7,8,9}$. This will reduce the chances of sepsis. Then the detached parts of tissues, fractured bones are placed in their normal position. Achievement of complete haemostasis is confirmed and wound is stitched with suture material inserted in a needle. The most important steps in the prevention of infection in a traumatic wound involve preparation, irrigation and debridement. The importance of meticulous wound care cannot be overemphasized. All devitalized tissue needs to be removed so that possibility of infection is markedly reduced.

The process of wound infection and its disadvantages were not unknown to ancients. Sushruta has clarified that blood clots, foreign materials like stones, hair, nails, fragment of fractured bone etc should be removed and wound should be thoroughly cleaned and then apply suture $^{10}$. If these materials are not removed, the 
wound will proceed to Pakavastha i.e. suppuration and will increase pain over affected part.

\section{Methods Of Wound Closure (Sevana Karma)}

Four methods of suturing techniques are described in Sushruta Samhita and other ancient Ayurvedic texts as Sevana Karma ${ }^{11}$ -

$>$ Vellitaka - Continuous type. This is achieved by suturing continuously along the length of the wound rapping the wound edges inside it.

$>$ Gophanika - Interlocking or blanket type suturing. The wounds which are shaped as footprints of crow, they are sutured with Gophanika type of suturing.

$>$ Tunnasevani - Zigzag type or subcuticular. It is done as like as the torn up garments are sutured.

Riju granthi -Straight and interrupted type. This type of suturing thread is inserted from two edges of wound and knot is tied. This is interrupted type of suturing.

\section{Materials used in suturing}

Sushruta Samhita is one of the Indian surgical texts which includes detail description about different types of suture materials both vegetative and animal origin which are either absorbable or non-absorbable. Sushruta had worked with many natural materials like fine threads, flax of Ashmantak (Bauhinia vahlii), Guduchi Pratan (Tinospora cordifolia), Trinaushadhi like Shanaj (a type of grass), Cotton threads, Silk threads, hairs of horse and Snayu ${ }^{13}$ (tendons/ligaments).

He had used the Heads of Giant Ants to effectively staple a wound over intestine while performing surgery for perforations. The live creatures were affixed to the edges of the wound, which they clamped shut with their pincers. Then the physician cut the insects' bodies off, leaving the jaws in place.

\section{Indication of wound closure:}

Brihattrayi were agreed on the fact that suturing should be resorted to the case of an open ulcer due to the action of the deranged fat after its vitiated contents has been fully scrapped out as well as in the case of an uncomplicated Sadyo Vrana. Importance is given to Sadyo Vrana and clearly mentioned that the wound should be sutured at the same day.

Dalhana in his commentary on Sushruta has elaborated this principle as wounds over head, forearm, face, ears, lips, nose, cheek, neck, upper extremities, abdomen, gluteal region, reproductive organs, penis, scrotum etc. are to be sutured immediately. Acharya Vagbhata stated that immediate suturing should be done in excised or hanged out tissues. Charakacharya described that the flanks, bowels, abdomen etc which are subjected to deep surgery should be sutured ${ }^{14}$.

\section{Contraindication of wound closure}

Acharya Sushruta clearly mentioned that the wounds contaminated with dust, poisonous wounds, diabetic wounds, skin diseases, putrificated, gangrenous wounds, wounds from which air is leaking, burns due to alkali (Kshar) or heat (Agni), infected wounds are not to be sutured $^{15}$. In case if the wound is contaminated, one should clear the wound then suture it in all possible aseptic precautions.

The wounds containing any foreign body inside it like bony sequestrations in osteomyelitis or the wounds where complete haemostasis is not achieved i.e. fresh bleeding in the wounds, penetrating injuries where there is presence of internal haemorrhage or haematoma, in such conditions wound should be left open and should not undergo suturing procedure.

Dalhanacharya comments that the wounds over the joints like knee, elbow etc where bones are fractured or dislocated and where much tissue is lost should not be sutured. 


\section{Benefits of suturing}

Acharya explained in various way that Sevana is an important karma among the Asthavidha Shalya Karma specially the wounds made during surgical procedure or appeared in traumatic injury. The suture approximate the both edges of wound, prevent hemorrhage, prevent contamination to various infective organisms and facilitate improve healing and decrease scar formation that also decrease the pain to patients also.

\section{Complication of incorrect suturing}

Acharya Sushruta explain that if during suturing if bite are taken at very near of edge the margin may be tear and results in wound dehiscence and if the suture are taken very far from the margin there may be tension suture which cases very much pain at the operative site $^{16}$. So the needle should be passed neither very far nor very near from the margins of wound.

\section{Discussion}

Our Achayas were very much aware about management of wounds. Acharya Sushruta described sixty Upakramas (procedures) for the treatments of wound ${ }^{17}$. The Sevana Karma is an important procedure in Shalya Karma. As I described earlier the method of suturing are similar in modern day surgical practice are also same. Sutures neither only facilitates wound healing but also stop the bleeding which occurs during surgery. The ancients well knew the interference of blood in repair and regeneration of wounds. The rakta vitiated by vata causes dehiscence of wound, vitiated by pitta causes suppuration, vitiated by kapha causes itching of the wounds. Large amount of bleeding causes inflammation and ischemia hampers the wound healing. Blood is a uniting factor of wound edges, which is very important in wound healing. Keeping this very important factor in view, Sushruta had advised to confirm the circulation of the part before uniting. If there is poor perfusion and marked ischemia of the part then one should scrap the wound margin and let the blood flow to improve and thereafter proceed for suturing.

Sushruta had given prime importance to achieve haemostasis while performing any surgical intervention. For the purpose, the act of tying bleeding vessels i.e. ligation was well known also various other methods like Sandhan ${ }^{18}$ (union) with suturing the wound will stop bleeding by applying pressure effect over small vessels and oozes, Skandana (coagulation) with kashayaushadhi and cold application so that the cut edge of bleeding vessel will shrunk and bleeding will stop, Dahana (cauterization) with Agni and Pachana (chemical cautery) by means of bhasmas (alkalis).

Acharya Sushruta gives the very much importance to wound closure to prevent secondary infection because open wounds are more prone to be infected. Infected wounds takes more time in healing because suturing is contraindicated in the infected wound, in that particular condition we first drain the pus and debridement of unhealthy tissue and make a good environment for the healing. So with the proper correct suturing save the wound to be infected and well approximation of edges provides small scar of surgery.

\section{Conclusion}

After studying all the review we can conclude that our ancients had very good sense of wound management. They gave similar importance to surgical as well as traumatic wound. They have very good idea of absorbable and non absorbable suture. In modern day we follow the same principle for the closure of wound.

\section{References}

1. Sushruta Samhita, Nibandh Sangrah and Nyaya Chandrika commentary by dalhana, jadavji T, Chaukhambha Sanskrit Sansthan Varanasi, p2.

2. Shastri A.D. in Sushruta Samhita: Ayurveda Tatva Sandipika, Chaukhambha Sanskrit Sansthan, Varanasi, sutra sthanam chapter, $5 / 5$ p-15. 
3. Shastri A.D. in Sushruta Samhita: Ayurveda Tatva Sandipika, Chaukhambha Sanskrit Sansthan, Varanasi, sutra sthanam chapter, 25/16 p-104.

4. Shastri A.D. in Sushruta Samhita: Ayurveda Tatva Sandipika, Chaukhambha Sanskrit Sansthan, Varanasi, chikitsa sthanam chapter, 1/45 p-7.

5. Shastri Kashinath, chatuirvedi G.N., Charak Samhita: Elobarated vidhyotani hindi commentary, Chaukhambha Bharati Academy, varanasi, chikitsa sthanam chapter 25/60 p-706

6. http://wiki.answers.com/q/who_is_the_ father of surgery.

7. Das. S., A practical guide to operative surgery, Method of wound closure and drainage, dr.S Das 13, Old Mayor's court, Kolkata700005, India, fifth edition, page 22.

8. Bailey \& Love, Short practice of surgery Edited by Norman S. Williams et-al, Edward Arnold publishers Ltd.,25 ${ }^{\text {th }}$ edition, Wound, tissue repairs and Scar, chapter $3 /$ p-26

9. Margaret Farquharson \& Brendan Moran, Farquharson's textbook of operative general surgery Hodder Arnol, North Hampshire Hospital, Basingstoke, UK, Ninth edition, General technique,p-5

10. Shastri A.D. in Sushruta Samhita: Ayurveda Tatva Sandipika, Chaukhambha Sanskrit Sansthan, Varanasi, sutra sthanam chapter, 25/18, 19 p-104.

11. Shastri A.D. in Sushruta Samhita: Ayurveda Tatva Sandipika, Chaukhambha Sanskrit Sansthan, Varanasi, sutra sthanam chapter, 25/21,22 p-104

12. Shastri A.D. in Sushruta Samhita: Ayurveda Tatva Sandipika, Chaukhambha Sanskrit Sansthan, Varanasi, sutra sthanam chapter, 25/20 p-104.

13. Shastri A.D. in Sushruta Samhita: Ayurveda Tatva Sandipika, Chaukhambha
Sanskrit Sansthan, Varanasi, sutra sthanam chapter, 25/20,21,23,24 p-10

14. Shastri Kashinath, chatuirvedi G.N., Charak Samhita: Elobarated vidhyotani hindi commentary, Chaukhambha Bharati Academy, varanasi, chikitsa sthanam chapter 25/60 p-706

15. Shastri A.D. in Sushruta Samhita: Ayurveda Tatva Sandipika, Chaukhambha Sanskrit Sansthan, Varanasi, sutra sthanam chapter, 25/17 p-104

16. Shastri A.D. in Sushruta Samhita: Ayurveda Tatva Sandipika, Chaukhambha Sanskrit Sansthan, Varanasi, sutra sthanam chapter, 25/26 p-105

17. Shastri A.D. in Sushruta Samhita: Ayurveda Tatva Sandipika, Chaukhambha Sanskrit Sansthan, Varanasi, chikitsa sthanam chapter, 1/134 p-13.

18. Shastri A.D. in Sushruta Samhita: Ayurveda Tatva Sandipika, Chaukhambha Sanskrit Sansthan, Varanasi, sutra sthanam chapter, 14/39,40 p-55 